\title{
Deguelin suppresses angiogenesis in human hepatocellular carcinoma by targeting HGF-c-Met pathway
}

\author{
Ming Li ${ }^{4,5, *}$, Xinfang Yu ${ }^{6, *}$, Wei Li ${ }^{7, *}$, Ting Liu ${ }^{1}$, Gang Deng ${ }^{8}$, Wenbin Liu' ${ }^{9}$, Haidan Liu ${ }^{3}$ \\ and Feng $\mathrm{GaO}^{1,2}$ \\ ${ }^{1}$ Department of Ultrasonography, The Third Xiangya Hospital of Central South University, Changsha, Hunan 410013, \\ P.R. China \\ ${ }^{2}$ State Key Laboratory of Powder Metallurgy, Central South University, Changsha, Hunan 410006, P.R. China \\ ${ }^{3}$ Clinical Center for Gene Diagnosis and Therapy, The Second Xiangya Hospital of Central South University, Changsha, Hunan \\ 410011, P.R. China \\ ${ }^{4}$ School of Stomatology, Hunan University of Chinese Medicine, Changsha, Hunan 410208, P.R. China \\ ${ }^{5}$ Changsha Stomatological Hospital, Changsha, Hunan 410004, P.R. China \\ ${ }^{6}$ Department of Cancer Biology, Lerner Research Institute, Cleveland Clinic, Cleveland, Ohio 44195, USA \\ 7 Department of Radiology, The Third Xiangya Hospital of Central South University, Changsha, Hunan 410013, P.R. China \\ ${ }^{8}$ Department of Hepatobiliary and Pancreatic Surgery, The Third Xiangya Hospital of Central South University, Changsha, \\ Hunan 410013, P.R. China \\ ${ }^{9}$ Hunan Cancer Hospital and The Affiliated Cancer Hospital of Xiangya School of Medicine, Central South University, Changsha, \\ Hunan 410013, P.R. China \\ *These authors contributed equally to this work \\ Correspondence to: Haidan Liv, email: Ihd1129@126.com \\ Feng Gao, email: gfeng0731@gmail.com
}

Keywords: hepatocellular carcinoma; deguelin; angiogenesis; VEGF; C-Met

Received: July 20,2016 Accepted: October 11,2017 Published: October 26, 2017

Copyright: Li et al. This is an open-access article distributed under the terms of the Creative Commons Attribution License 3.0 (CC BY 3.0), which permits unrestricted use, distribution, and reproduction in any medium, provided the original author and source are credited.

\section{ABSTRACT}

Angiogenesis plays a crucial role in the development of human hepatocellular carcinoma (HCC). In the present study, we found a natural compound, deguelin, has a profound anti-angiogenesis effect on HCC. Deguelin suppressed vascular endothelial growth factor (VEGF)-induced human umbilical vascular endothelial cells (HUVECs) proliferation, migration, invasion, and capillary-like tube formation in vitro and reduced tumor angiogenesis in vivo. We discovered that VEGF receptor-mediated signal transduction cascades in HUVECs were inhibited by deguelin. Deguelin decreased the autocrine of VEGF in HCC cells in a time- and dose-dependent manner. Additionally, deguelin suppressed HGF-induced activation of the c-Met signaling pathway. Knocking down c-Met or inhibition of c-Met activation impaired HGF-mediated VEGF production. Importantly, we produced patient-derived hepatocellular carcinoma xenografts to evaluate the therapeutic effect of deguelin in vivo. Taken together, these results indicate that deguelin could inhibit HCC through suppression of angiogenesis on vascular endothelial cells and reduction of proangiogenic factors in cancer cells.

\section{INTRODUCTION}

Tumor angiogenesis, the development of new blood vessels from the existing vasculature, is considered to play an essential role in malignant neoplasia development [1]. It is estimated that over $90 \%$ cancer deaths that occur are due to angiogenesis, invasion, and distant metastasis of cancer to vital organs [2]. The proliferation and migration of endothelial cells in response to chemotactic agents, such as vascular endothelial growth factor (VEGF), are considered a key step in the initiation of angiogenesis [3]. VEGF exerts its biological effects by binding to its receptor tyrosine kinases, VEGFR1, VEGFR2, and VEGFR3. VEGFR2 plays an important role in mediating 
the mitogenesis and permeability of endothelial cells [4]. Activation of VEGFR2 leads to the phosphorylation of various downstream signal transduction pathways, including extracellular signal-regulated kinases (ERK), protein kinase $\mathrm{C}$, Src family kinase, focal adhesion kinase, and PI3-K/AKT pathway [4, 5]. VEGFR2 targeting therapies or angiogenesis blockade has been shown to be an effective strategy in inhibiting tumor growth and metastasis [6-8].

Hepatocellular carcinoma (HCC), the most common primary liver tumor, is one of the most aggressive and lethal malignancies. Overall, the 5-year survival rate for patients with $\mathrm{HCC}$ of any stage is about $15 \%$. Resistant to systemic therapies and often recurs even after aggressive local therapies are the main problems in HCC treatment $[9,10]$. Understanding the molecular mechanisms of the complex multistep process of HCC could facilitate the development of preventive measures, early diagnostic methods, and better treatments. The formation of new blood vessels plays a key role in HCC, which is responsible for the rapid recurrence and poor survival. New vessel formation with abnormal structure and function leads to an abnormal tumor microenvironment characterized by low oxygen tension. The liver is perfused by both arterial and venous blood and the resulting abnormal microenvironment selects for more aggressive malignancies [11, 12]. Indeed, a large number of antiangiogenic agents, such as bevacizumab [13], Sorafenib [14, 15] and Sunitinib [16, 17], are currently being tested for the treatment of advanced-stage HCC.

Deguelin, a natural product isolated from several plant species such as Mundulea sericea, has been demonstrated that it exerted anti-proliferation activities and/or induce apoptosis in a panel of human cancers, such as lung cancer [18-20], colon cancer [21], pancreatic Cancer [22], prostate cancer [23] and breast cancer $[24,25]$. Mechanism investigation manifested that deguelin treatment resulted in cell cycle arrest [26], induction of apoptosis [27], inhibition the activities of NF-KB [28] and PI3K/Akt signaling pathways [18]. Nonetheless, the anti-tumor activity of deguelin in hepatocellular carcinoma, as well as the effect on tumor angiogenesis has not yet been fully investigated.

In this study, we have identified deguelin as a novel inhibitor of tumor angiogenesis and characterized its underlying molecular mechanisms. The anti-angiogenic properties of deguelin were evaluated in vitro using HUVECs proliferation, migration, and tubular formation assays and in vivo by Matrigel plug assay. Moreover, we demonstrated that deguelin suppressed VEGF secretion in an $\mathrm{HGF} / \mathrm{c}-\mathrm{MET}$ axis dependent manner in HCC cells. Most importantly, we evaluated the possible clinical use of deguelin by investigating its therapeutic effects in patient-derived xenografts (PDXs) of primary human hepatocellular carcinoma.

\section{RESULTS}

\section{Deguelin inhibits hepatocellular carcinoma cells growth in vitro and in vivo}

First, we investigated the activity of deguelin (Figure 1A) against hepatocellular carcinoma cells proliferation in Hep3B, HepG2 and MHCC97-H cells. MTS data showed that deguelin significantly decreased the anchorage-dependent growth of Hep3B, HpeG2 (Figure 1B), and MHCC97-H cells (Supplementary Figure 1A) in a dose-dependent manner. Moreover, Treatment with deguelin dramatically inhibited anchorageindependent cell growth in Hep3B, HepG2 (Figure 1C) and MHCC97-H cells (Supplementary Figure 1B). In order to further confirm the antitumor activity of deguelin, the potency of deguelin against HCC cell growth was investigated in vivo. As shown in Figure 1D-1F, tumor growth in the deguelin-treated group was delayed in contrast with the vehicle group. The average tumor volume of vehicle treated group had reached about 800 $\mathrm{mm}^{3}$, but in deguelin treated group, the average tumor volume was only around $300 \mathrm{~mm}^{3}$. Meanwhile, during the treatment period, deguelin did not affect the body weight obviously (Figure 1G). Our results found that deguelin can't significantly induce the up/down-regulation of the AST, ALT and BUN, which indicated that the deguelin has no obvious hematotoxicity (Supplementary Figure 2). Immunohistochemistry analysis revealed that the positive staining of Ki67 in tumor tissue was substantially decreased after deguelin treatment, which confirmed the anti-proliferation activity of deguelin on HCC in vivo. Interestingly, we found that CD31 staining for newly formed blood vessels in deguelin treated group was decreased by $60 \%$ compared to vehicle-treated group (Figure 1H), which indicated that the anti-tumor effect of deguelin may partly dependent on the inhibition of angiogenesis.

\section{Deguelin decreases cell proliferation in HUVECs}

To assess the antiangiogenic property of deguelin in vitro, we examined the inhibitory effects of deguelin on cell proliferation of HUVECs. Our results showed that deguelin had no obvious effect on cell proliferation at a low concentration (1-2 $\mu \mathrm{M})$ but substantially inhibited HUVECs growth after the concentration reached $>4 \mu \mathrm{M}$ (Figure 2A). Moreover, deguelin significantly suppressed VEGF-induced endothelial cell proliferation from $2 \mu \mathrm{M}$ (Figure 2B), indicating that deguelin is more effective in angiogenesis disease condition. To examine whether deguelin-mediated HUVECs suppression was related to cell cycle progression deregulation, we performed FACS analysis. The results revealed that deguelin-induced accumulation of cells at G2/M phase (Figure 2C). These 
A<smiles>COc1cc2c(cc1OC)[C@H]1C(=O)c3ccc4c(c3O[C@H]1CO2)C=CC(C)(C)O4</smiles>

B
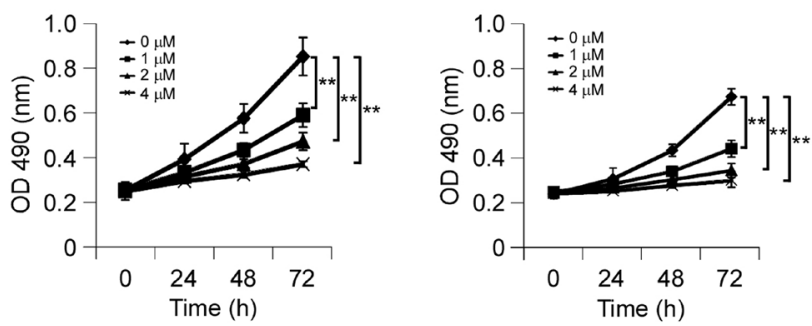

C Deguelin $(\mu \mathrm{M})$
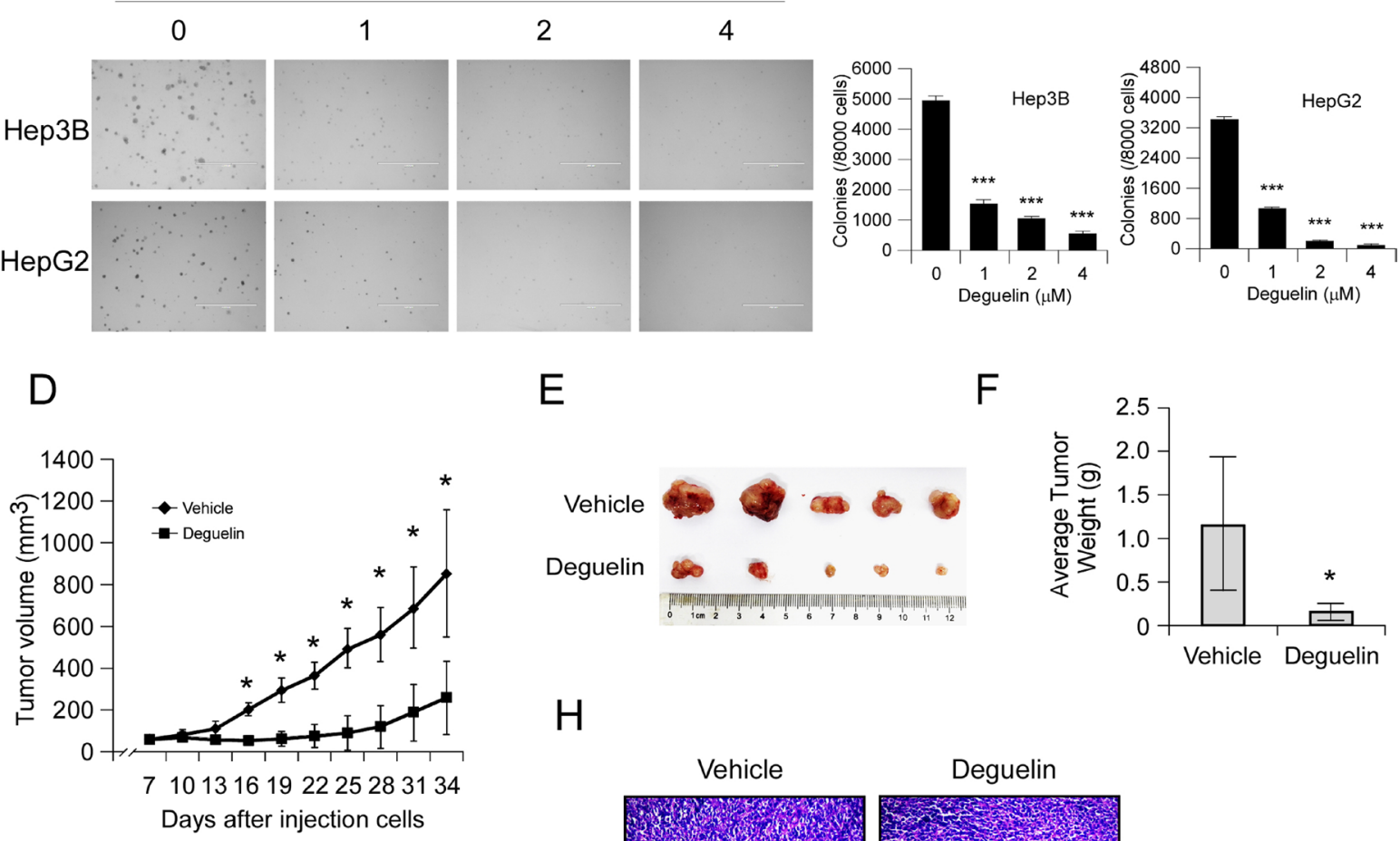

E

F

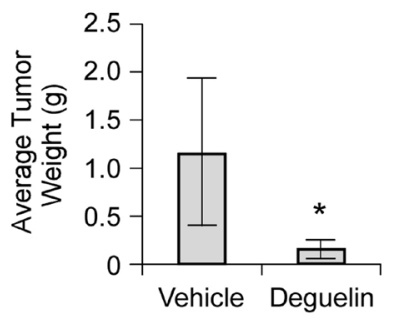

$\mathrm{H}$

$\mathrm{HE}$

G
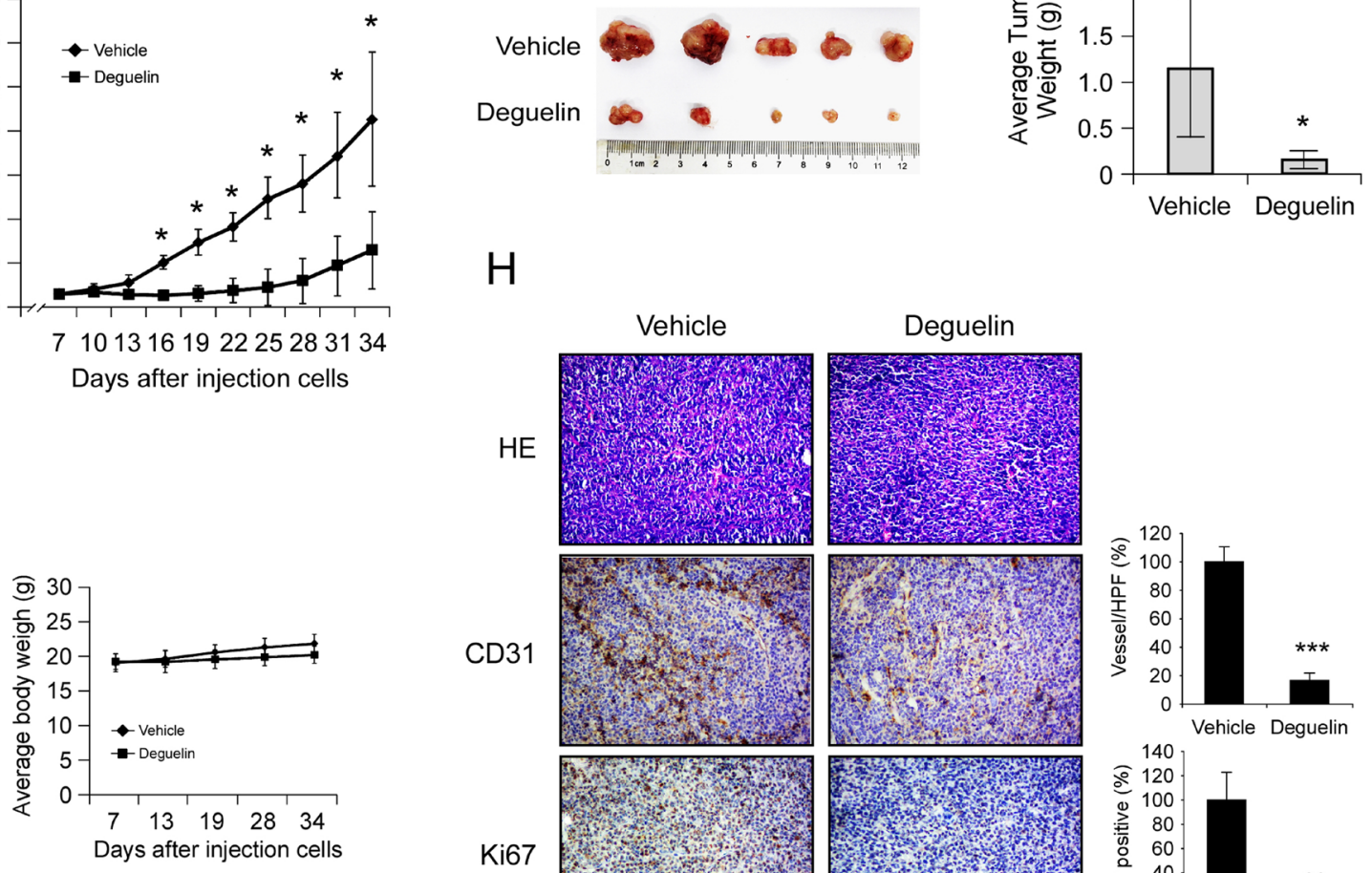

CD31
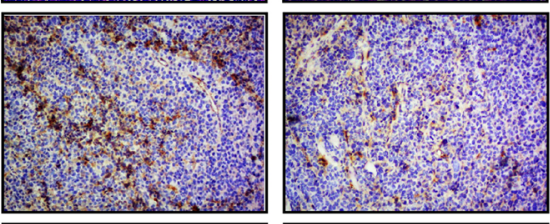

Deguelin
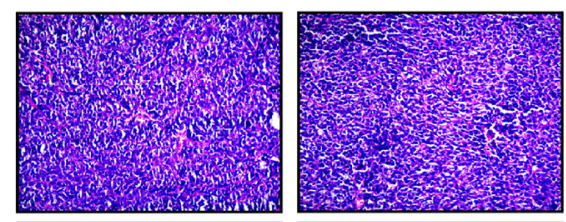

Ki67
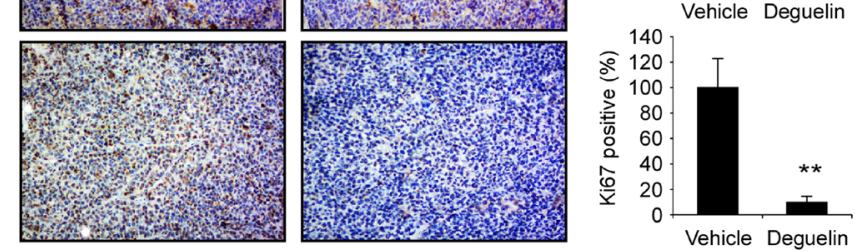

Figure 1: Deguelin inhibits hepatocellular carcinoma cells growth in vitro and in vivo. (A) Chemical structure of deguelin. (B) Deguelin decreases cell growth. Hep3B (left) and HepG2 (right) cells were treated or not treated with deguelin as indicated, MTS assay was performed as described in Materials and Methods. The asterisk $\left(^{* *}\right)$ indicates a significant $(p<0.01)$ decrease in cell proliferation by deguelin-treated cells. (C) Deguelin attenuates Hep3B and HepG2 anchorage-independent cell growth. Soft agar assay was performed as described in Materials and Methods. The asterisk $\left(^{* *}\right)$ indicates a significant $(p<0.001)$ decrease in colony formation by deguelin-treated cells. (D-G) Deguelin inhibits tumor growth in vivo. (D) Tumor growth curve, (E) photograph of tumors in the vehicle and deguelin-treated group, $(\mathrm{F})$ average tumor weight, $(\mathrm{G})$ average body weight of mice. Data are represented as means \pm SD of each group. The asterisk ( $\left.{ }^{*}\right)$ indicates a significant difference $(p<0.05)$ compared with the deguelin-treated group. (H) Immunohistochemical examination of CD31 and Ki67 in tumor sections. Left panel, a representative photograph of tumor tissue per group (200×); right panel, the expression of indicated protein in per group was quantified, the asterisks $\left({ }^{* * *} p<0.001\right)$ indicates a significant difference. 
data suggested that deguelin could arrest HUVECs cell cycle progression in vitro.

\section{Deguelin suppresses VEGF-induced migration, invasion, capillary tube formation of HUVECs in vitro and VEGF-induced angiogenesis in vivo}

Cell migration is a critical step for the endothelial cell to form blood vessels in angiogenesis. Based on the previous data, we further determined the inhibitory effects of deguelin on the chemotactic motility of endothelial cells using the wound-healing migration assay and transwell assay, respectively. The results showed that deguelin significantly inhibited VEGF-induced HUVECs migration in a dose-dependent manner (Figure 3A). Because directional motility and matrix degradation are crucial for angiogenesis sprouting, we next used the Boyden chamber transwell assay to determine whether deguelin
A

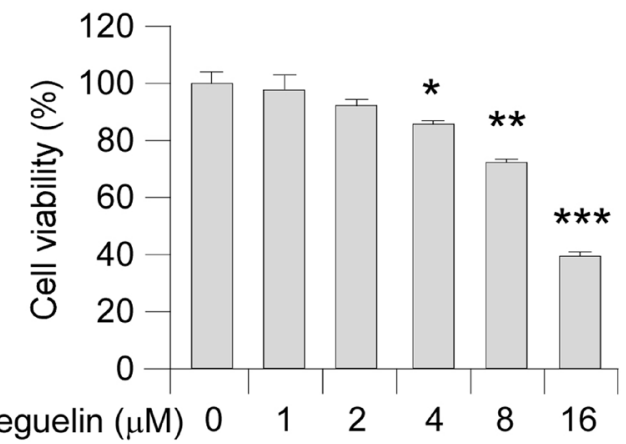

B

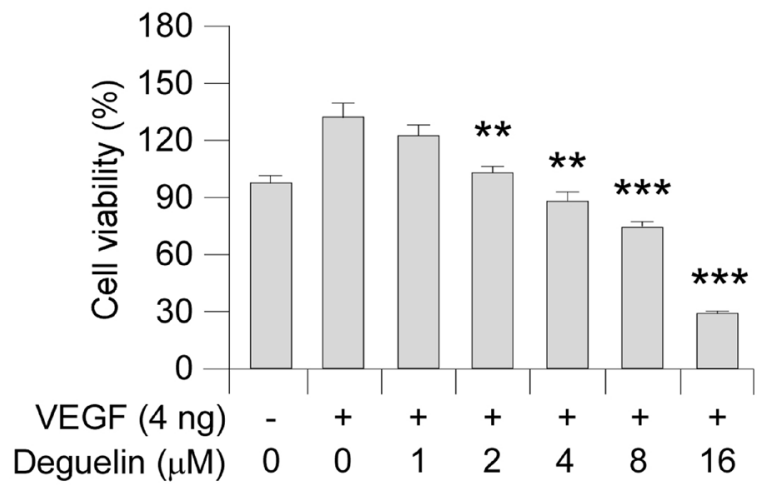

\section{C}

DMSO

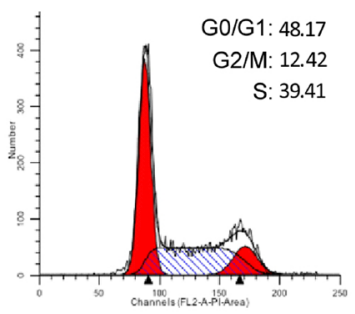

Deg: $2 \mu \mathrm{M}$

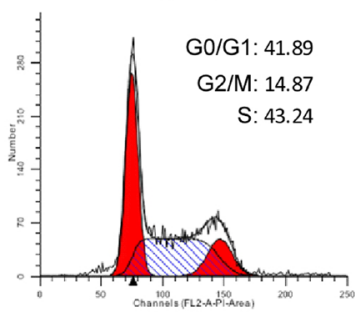

Deg: $1 \mu \mathrm{M}$

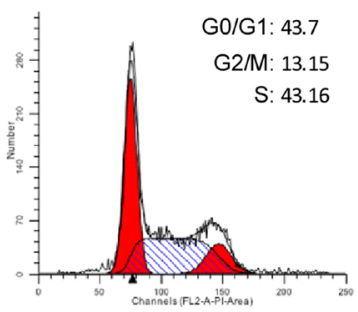

Deg: $4 \mu \mathrm{M}$

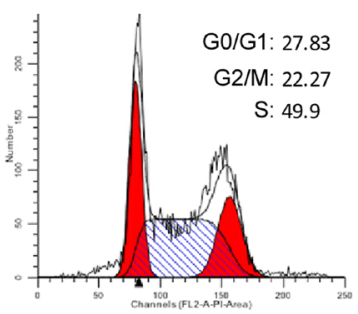

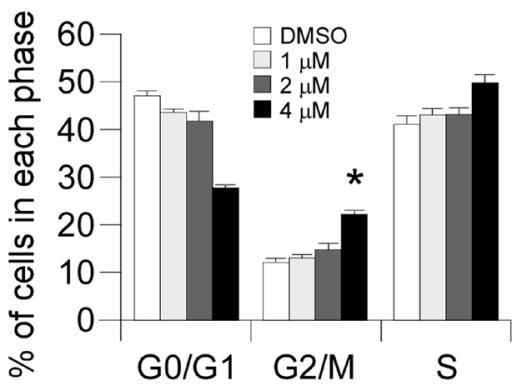

Figure 2: Deguelin inhibits the proliferation of HUVECs. (A) Effects of deguelin on HUVECs proliferation under normal culture condition. HUVECs $\left(2 \times 10^{4}\right.$ per well $)$ were treated with different concentrations of deguelin for $24 \mathrm{~h}$, cell proliferation was tested by MTS assay. The asterisk indicates a significant $\left({ }^{*} p<0.05,{ }^{* *} p<0.01,{ }^{* * *} p<0.001\right.$, ) decrease in cell proliferation by deguelin-treated cells. (B) Deguelin inhibits VEGF-induced cell proliferation in a dose-dependent manner. HUVECs $\left(2 \times 10^{4}\right.$ per well $)$ were starved with $0.5 \%$ FBS medium and then treated with or without VEGF $(4 \mathrm{ng} / \mathrm{mL})$ and different concentrations of deguelin for 24 h. Cell proliferation was quantified by MTS assay. The asterisk indicates a significant $\left({ }^{* *} p<0.01,{ }^{* * *} p<0.001,\right)$ decrease in cell proliferation by deguelin-treated cells. (C) Deguelin-induced cell cycle G2/M arrest. HUVECs were treated as described in Materials and Methods, and flow cytometry analysis was used to analyze deguelin-induced cell cycle arrest. The asterisk indicates a significant $\left({ }^{*} p<0.05\right)$ increase in $\mathrm{G} 2 / \mathrm{M}$ phase after deguelin treatment. 
A

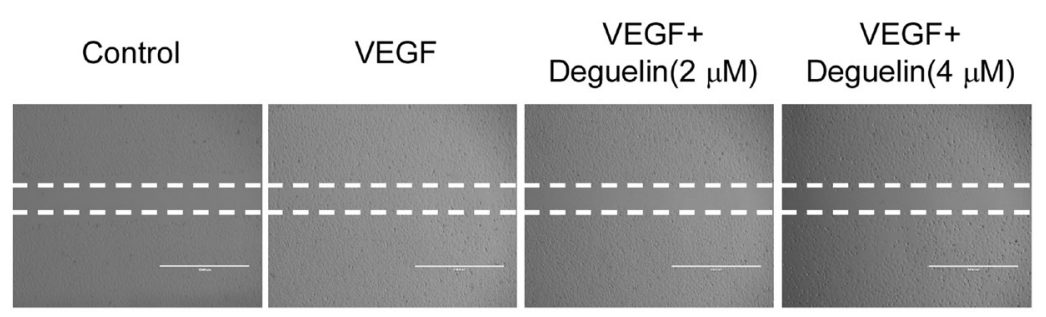

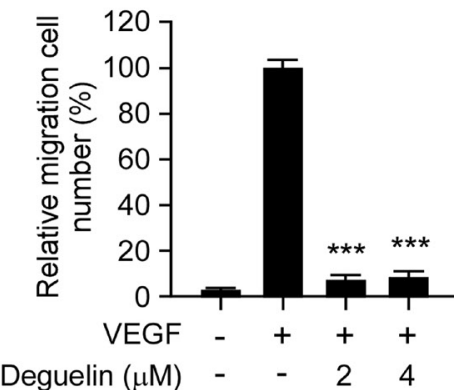
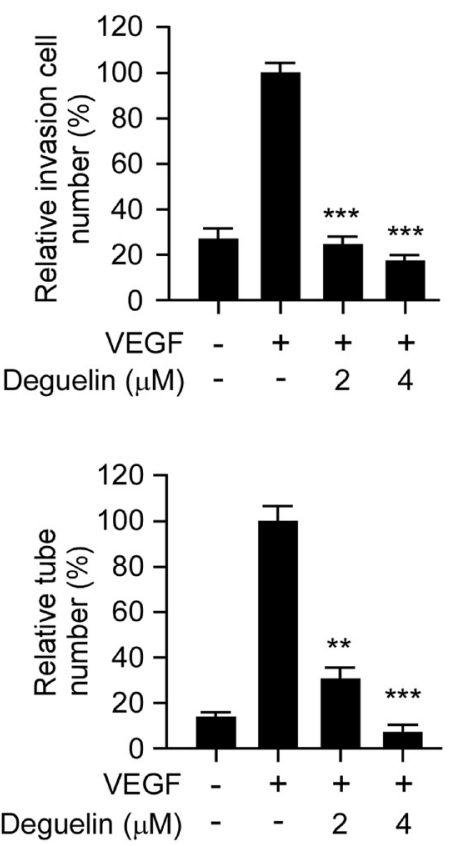

Deguelin $(\mu \mathrm{M})$

Deguelin $(\mu \mathrm{M})$

D
Control

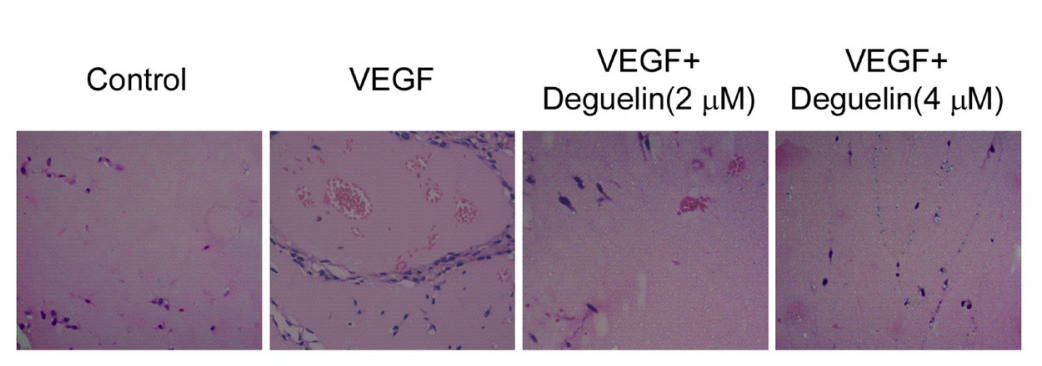

VEGF

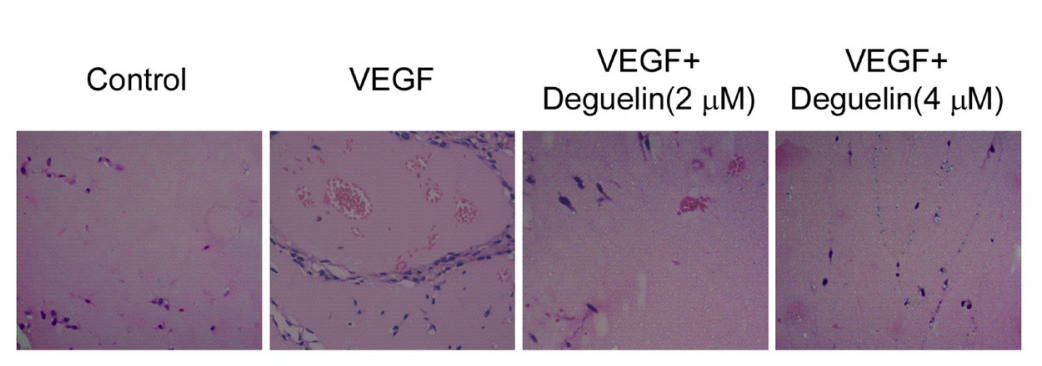

VEGF+ Deguelin $(2 \mu \mathrm{M})$

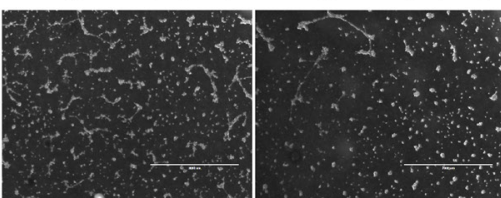

VEGF+
VEGF+ Deguelin $(4 \mu \mathrm{M})$
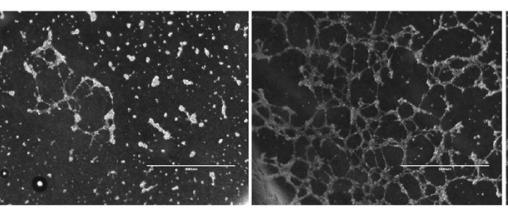

Deguelin $(2 \mu \mathrm{M})$

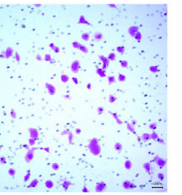

VEGF

B

C

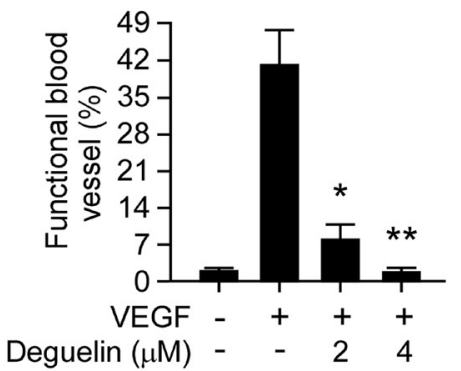

Figure 3: Deguelin suppresses VEGF-induced migration, invasion, capillary tube formation of HUVECs in vitro and VEGF-induced angiogenesis in vivo. (A) HUVECs were allowed to grow to full confluence in six-well plates and starved in $0.5 \%$ FBS medium. Cells were scratched with a pipette tip, then treated with different concentrations of deguelin and $10 \mathrm{ng} / \mathrm{mL}$ VEGF in M199 supplemented with $0.5 \% \mathrm{FBS}$ as indicated. After $12 \mathrm{~h}$, the migrated cells were quantified by manual counting. (B) HUVECs were seeded in the upper chamber of a Transwell slide and treated with different concentrations of deguelin. The bottom chamber was filled with ECGM supplemented with VEGF $(10 \mathrm{ng} / \mathrm{mL})$. After $8 \mathrm{~h}$, cells adherent on the lower surface of the filters were fixed and stained. Five representative fields were photographed under a light microscope and counted in triplicate to obtain invasion indices. (C) HUVECs were placed on the top of polymerized Matrigel in 24-well plates in the absence or presence of different concentrations of deguelin as indicated. After $8 \mathrm{~h}$, tubular structures were photographed. Tube formation was quantified by manual counting of high power fields (HPFs). (D) Matrigel $(0.5 \mathrm{~mL})$ containing VEGF (80 ng) and the indicated amounts of deguelin was injected into C57BL/6 mice in the midventral abdominal region ( 5 mice per group). After 7 days, Matrigel plugs were removed and fixed in formalin. Sections were stained with H\&E. The number of vessels in HPF was counted for 5 representative fields in triplicate under a light microscope. Left panel, a representative photograph of each group; right panel, the quantified data of each group. Each experiment was conducted 3 times and the data are expressed as mean values \pm S.D. $\left({ }^{*} p<0.05,{ }^{* *} p<0.01,{ }^{* * *} p<0.001\right.$ versus VEGF-treated group). 
affected the motility of HUVECs. Our results showed that deguelin dramatically reduced cell invasion (Figure 3B). Next, the ability of endothelial cells to form tube-like structures was assessed with an inverted photomicroscope. We found that robust tubular-like structures were formed in the presence of VEGF, but exposure to deguelin dosedependently down-regulated VEGF-induced tubule formation of HUVECs (Figure 3C). We further performed the mouse matrigel plug assay to analyze how deguelin regulated VEGF-induced angiogenesis in vivo. Matrigel and heparin were mixed or not mixed with deguelin $(2 \mu \mathrm{M}$ and $4 \mu \mathrm{M})$. The mixture was injected into C57BL/6 mice, and the Matrigel plugs were removed after 7 days. The plugs containing VEGF alone appeared dark red, whereas the color of the Matrigel plugs containing VEGF plus deguelin was substantially paler, indicating less blood vessel formation (data not shown). Hematoxylin and eosin (H\&E) staining showed that the plugs containing VEGF alone exhibited functional vasculature formation inside the Matrigel through angiogenesis. In contrast, deguelin dramatically decreased VEGF-induced microvessel number in a dose-dependent manner (Figure 3D). Taken together, these results indicated that deguelin was capable of suppressing VEGF-induced neovessel formation both in vitro and in vivo.

\section{Deguelin down-regulates VEGF production in HCC cells and suppresses VEGFR2 signaling pathway in HUVECs}

In order to explore the mechanism involved in deguelin-mediated anti-angiogenesis effect, we first determined the autocrine of VEGF in Hep3B and HepG2 cells via ELISA assay. Results showed that the VEGF protein levels in the cell culture medium were significantly decreased in a dose-dependent manner in deguelin treated group, and the HepG2 cell secreted much higher levels of VEGF than the Hep3B cell (Figure 4A, 4B). Moreover, we found that deguelin decreased VEGF production in a time-dependent manner in both Hep3B and HepG2 cells (Figure 4C, 4D). VEGFR2 is the primary receptor in VEGF signaling pathway that regulates endothelial cell proliferation, migration, differentiation, tube formation, and angiogenesis. As shown in Figure 4E, deguelin substantially inhibited VEGF-induced VEGFR2, Akt and ERK1/2 activation (Figure 4E), which suggests that deguelin is a potential inhibitor of VEGFR2. Thus, we further examined the effects of deguelin on the specific activation of VEGFR2 using HTScan VEGFR2 kinase assay kit. We found that deguelin inhibited VEGFR2 activation directly in a dose-dependent manner (Figure 4F). These results suggested that the antiangiogenic property of deguelin may be at least partially dependent on the suppression of VEGF secretion and VEGFR2 activation.

\section{Deguelin inhibits VEGF production through HGF-cMet signaling pathway}

The HGF-c-Met signaling pathway is a hub in the regulation of malignant progression in HCC. Suppression of c-Met has been reported to inhibit angiogenesis through regulating the expression of angiogenesis factors, such as VEGF [29-31]. Indeed, we found that the secretion of VEGF in HepG2 cells was substantially upregulated with the stimulation of HGF (Figure 5A). Western blot analysis showed that the activation of the key components of c-Met signaling pathway, including phosphorylation of c-Met, Akt and ERK1/2 were decreased in deguelin-treated HepG2 cells (Figure 5B). Consistently, HGF-induced phosphorylation of c-Met, as well as the activation of its downstream signaling, was also inhibited by deguelin in a dosedependent manner (Figure 5C). Exposure to deguelin dramatically inhibited HGF-induced upregulation of VEGF secretion in HepG2 cells as expected (Figure 5D). To further elucidate the specific role of c-Met in the HGF-induced VEGF secretion, we constructed c-Met stable knocking down HepG2 cells. Our data showed that down-regulation of c-Met expression blocked HGF-increased VEGF production (Figure 5E, left). Overexpression of c-Met in HepG2 cells promotes HGFinduced VEGF secretion (Figure 5E, right). Furthermore, c-Met inhibitor also inhibited HGF-induced VEGF upregulation (Figure $5 \mathrm{~F}$ ). In order to confirm that deguelininduced VEGF secretion suppression was only dependent on HGF-c-Met signaling inhibition, we detected the effect of deguelin on other tyrosine kinase receptors, including EGFR and IGF1R $\beta$. We found that deguelin substantially inhibited EGFR activity (Supplementary Figure 3A) in HepG2 cell. Although EGF treatment activated the EGFR signaling pathway (Supplementary Figure 3B), the VEGF production in HepG2 cells was not promoted significantly (Supplementary Figure 3C). The further experiment showed that the EGFR specific inhibitor, gefitinib, had no obvious effect on VEGF secretion (Supplementary Figure 3D), and knockdown of EGFR in HepG2 cells didn't induce the decrease of VEGF production (Supplementary Figure 3E). As the data showed in Supplementary Figure 4A, deguelin can't effectively inhibit the activation of IGF1R $\beta$. Similarly, we also found that the IGF1R signaling pathway was not essential for deguelin-induced down-regulation of VEGF production, IGF1 can't dramatically increase the protein level of VEGF (Supplementary Figure 4B, 4C), and inhibited the activity of IGF1R $\beta$ by small-molecule inhibitor or knockdown of IGF1R $\beta$ by shRNA had no significant effect on VEGF secretion (Supplementary Figure 4D, 4E). Collectively, these results indicated that a c-Met activation is a critical event contributing to VEGF production in HCC cells. 


\section{In vivo antitumor efficacy of deguelin in human hepatocellular PDX tumor models}

To further confirm the antitumor activity of deguelin in vivo, we utilized a human hepatocellular PDX tumor model. This model is based on the transfer of primary

A

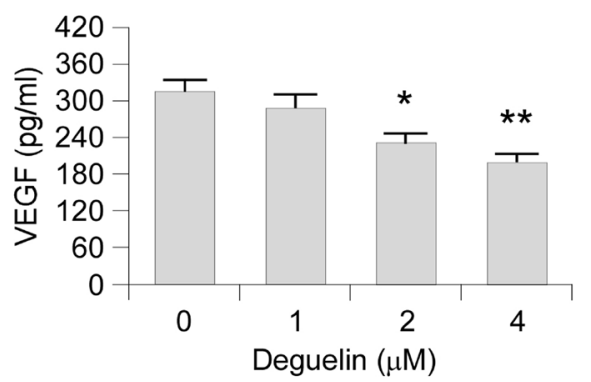

C

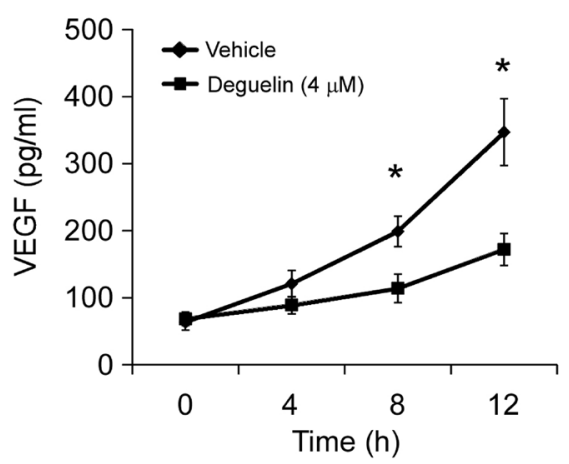

E

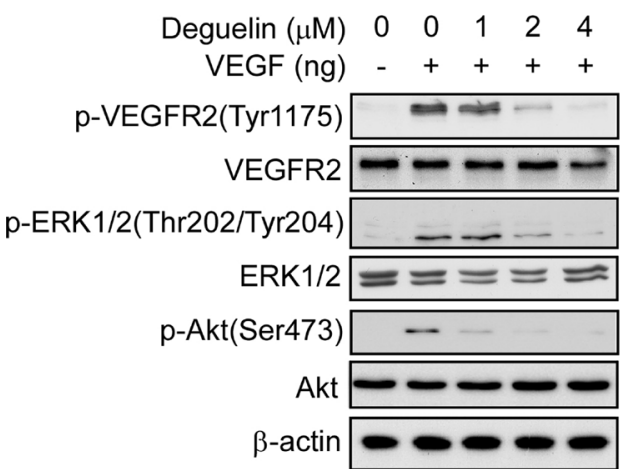

tumors directly from the human patient into an immune deficient mouse. We selected three tumors having the same cancer grade and stage in order to maintain consistency (Table 1). None of the PDX tumors received chemotherapy before surgery and subsequent implantation. After the original tumor specimen was serially passaged to treatment

B

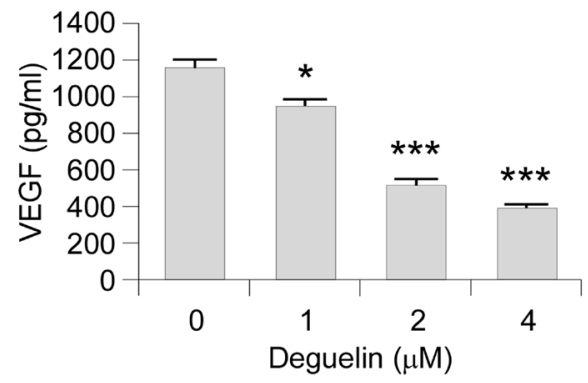

D

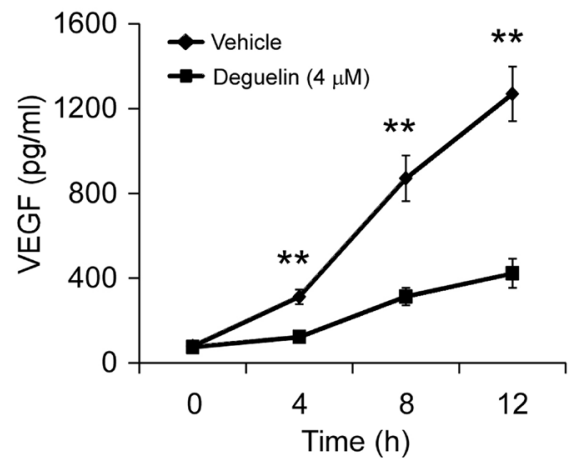

$\mathrm{F}$

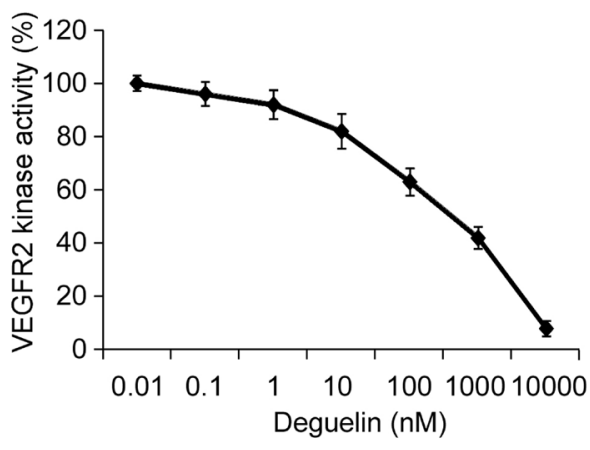

Figure 4: Deguelin inhibits VEGF production in HCC cells and suppresses VEGFR2 signaling pathway in HUVECs. (A) and (B) Hep3B (A) and HepG2 (B) cells were treated with different concentrations of deguelin for $12 \mathrm{~h}$. Cell culture media was harvested and VEGF level was measured by ELISA assay. (C) and (D) Hep3B (C) and HepG2 (D) cells were treated or not treated with $4 \mu \mathrm{M}$ deguelin. Cell culture media was harvested at different time points and VEGF level was measured by ELISA assay. (E) Deguelin inhibits VEGF-induced VEGFR2 activation in HUVECs. HUVECs were starved in $0.5 \%$ FBS medium overnight and treated with various dosages of deguelin for $2 \mathrm{~h}$, the cells were stimulated with VEGF $(40 \mathrm{ng} / \mathrm{ml})$ for $30 \mathrm{~min}$. Cell lysates were then subjected to SDS-PAGE followed by Western blotting. $\beta$-Actin served as a loading control. (F) Inhibition of deguelin on VEGFR2 activation in a specific VEGFR2 inhibition assay. The experiment was conducted 3 times and the data are expressed as mean values \pm S.D. $\left({ }^{*} p<0.05,{ }^{* *} p<0.01,{ }^{* * *} p<0.001\right.$ versus untreated/vehicle group). 
A

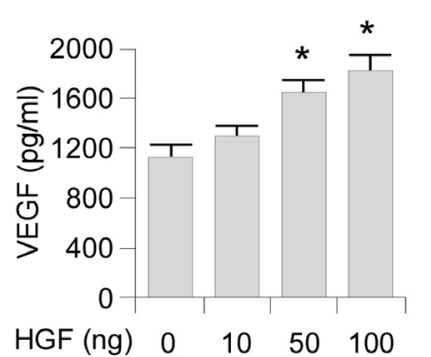

C

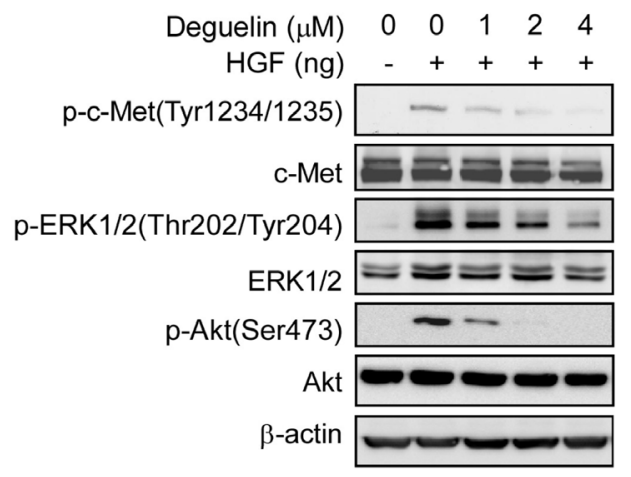

B

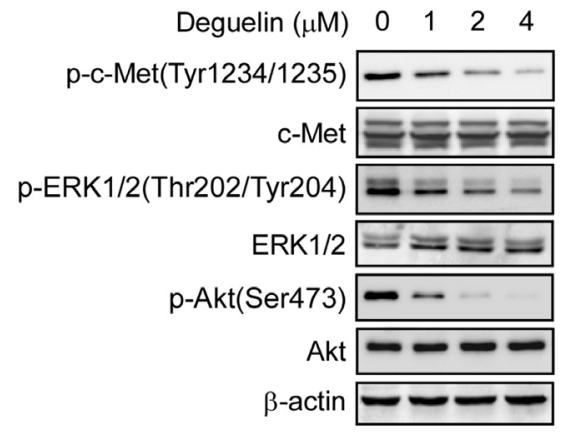

D

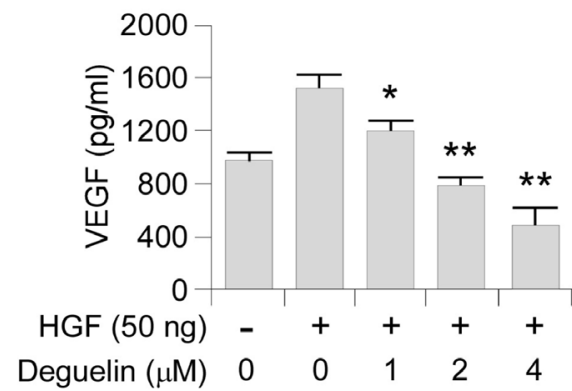

$\mathrm{E}$
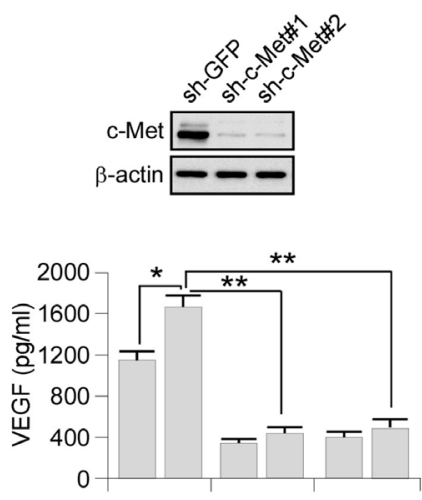

HGF (50 ng)

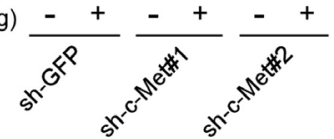

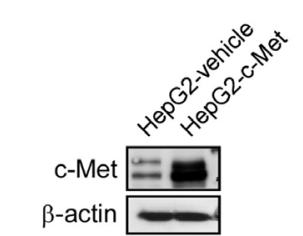

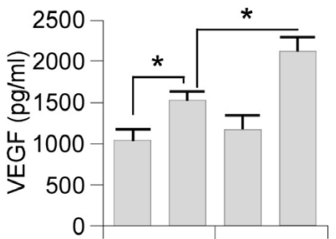

HGF (50 ng)

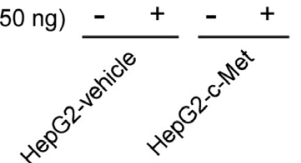

$\mathrm{F}$

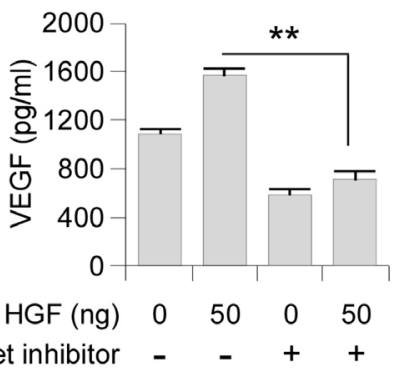

Figure 5: Deguelin inhibits VEGF production through HGF-cMet signaling pathway. (A) HGF promotes VEGF secretion. HepG2 cells were treated with different concentrations of HGF for $12 \mathrm{~h}$. Cell culture media was harvested and VEGF level was measured by ELISA assay. (B) Deguelin inhibits c-Met signaling pathway in HepG2. HepG2 cells were treated with various dosages of deguelin for $24 \mathrm{~h}$, cell lysates were subjected to SDS-PAGE followed by Western blotting as indicated. $\beta$-Actin served as a loading control. (C) Deguelin inhibits HGF-induced c-Met signaling pathway in HepG2. HepG2 cells were starved in $0.1 \%$ FBS medium overnight and treated with various dosages of deguelin for $2 \mathrm{~h}$, the cells were treated with HGF $(50 \mathrm{ng} / \mathrm{ml})$ for $30 \mathrm{~min}$. Cell lysates were subjected to SDSPAGE followed by Western blotting as indicated. $\beta$-Actin served as a loading control. (D) Deguelin inhibits HGF-induced VEGF secretion. HepG2 cells were pretreated with different concentrations of deguelin for $2 \mathrm{~h}$ and followed by HGF treatment for $12 \mathrm{~h}$. Cell culture media was harvested and VEGF level was measured by ELISA assay. (E) Knocking down (left) of c-Met impaired HGF-induced VEGF secretion. The c-Met expression was tested by Western blot (top). The sh-GFP and sh-c-Met cells were treated with or without HGF for $12 \mathrm{~h}$, cell culture media was subjected to ELISA assay. Overexpression of c-Met (right) promoted HGF-induced VEGF secretion. The c-Met expression was tested by Western blot (top). The HepG2-vehicle and HepG2-c-Met cells were treated with or without HGF for $12 \mathrm{~h}$, cell culture media was subjected to ELISA assay. (F) c-Met inhibitor suppresses HGF-induced VEGF secretion. HepG2 cells were pretreated with or without c-Met inhibitor for $2 \mathrm{~h}$ and followed by HGF stimulation for another $12 \mathrm{~h}$, cell culture media was subjected to ELISA assay. Each experiment was conducted 3 times and the data are expressed as mean values \pm S.D. $\left({ }^{*} p<0.05,{ }^{* *} p<0.01\right.$ versus untreated/vehicle group). 
Table 1: Clinical characteristics of the origin used in PDX tumor models

\begin{tabular}{lcclcccc}
\hline Model ID & Gender & Age $(\mathbf{y r s})$ & Source & Histology & Cancer grade & Cancer stage & Prior chemo \\
\hline Case $\mathbf{1}$ & Male & 51 & Primary & HCC & IIa & T2N0M0 & No \\
Case 2 & Male & 57 & Primary & HCC & IIa & T2N0M0 & No \\
Case 3 & Male & 59 & Primary & HCC & IIa & T2N0M0 & No \\
\hline
\end{tabular}

Abbreviations: HCC: hepatocellular carcinoma; T: tumor; N: lymph nodes; M: metastasis.

phase 3 (P3), vehicle or deguelin was administered by intraperitoneal injection. As shown in Figure 6A-6C, deguelin displayed a significant antitumor effect in PDX tumor model. At the endpoint, the average tumor weights of vehicle group and deguelin group in each case were $0.698 \pm 0.268 / 0.09 \pm 0.023 \mathrm{~g}, 1.094 \pm 0.329 / 0.251 \pm 0.249$ and $0.91 \pm 0.108 / 0.135 \pm 0.011$, respectively. Notably, no significant differences in body weights occurred among the three xenograft groups treated or not treated with deguelin (Figure 6D). All these in vivo data demonstrated that deguelin treatment provides positive effects on human hepatocellular carcinoma.

\section{DISCUSSION}

In the present study, we demonstrated that deguelin exerted a substantial anti-angiogenesis activity against human hepatocellular carcinoma. We uncovered that two major signaling pathways were involved in deguelinmediated neovascularization inhibition. First, deguelin decreased the activity of angiogenesis in endothelial cells via suppressing VEGF-induced VEGFR2 activation (Figures 2-4). Second, deguelin down-regulated the proangiogenic characteristics in hepatocellular carcinoma cells by inhibiting the secretion of VEGF through the inhibition of HGF-c-Met signaling pathway (Figures 4-5).

Deguelin exhibited significant anti-tumorigenesis and anti-proliferative activity in various types of human cancer both in vitro and in vivo. Deguelin induces cell apoptosis by blocking anti-apoptotic pathways, such as PI3K-Akt, IKK-I $\kappa \mathrm{B} \alpha-\mathrm{NF}-\kappa \mathrm{B}$ and AMPK-mTORsurvivin pathways. Furthermore, deguelin inhibits tumor cell propagation and malignant transformation through p27-cyclinE-pRb-E2F1 cell cycle control and HIF-1 $\alpha$ VEGF anti-angiogenic pathways [26]. Previous studies have demonstrated that deguelin suppressed the growth of human tumors in nude mouse models via the downregulation of tumor angiogenesis. $\mathrm{Hu}$ and colleagues showed that deguelin could inhibit the growth and lymphatic metastasis of human lung cancer through suppression of VEGFD pathway [32]. However, Lee and colleagues showed that deguelin suppressed the growth of human lung cancer cells by down-regulation of HIF $1 \alpha-$ mediated VEGFA expression [33] in both normoxia and hypoxia conditions. Other studies also indicated that the anti-angiogenesis activity was one of the major mechanisms which involved in deguelin-mediated gastric cancer [34] and hepatocellular carcinoma [35] inhibition. However, the molecular mechanism has not yet been fully elucidated. The role of VEGF and VEGFR2 in modulating tumor-vascular growth and function is well established in both preclinical models and cancer patients [36]. Here, we demonstrated that deguelin inhibited VEGF-induced VEGFR2 activation, as well as the phosphorylation of downstream targets Akt and ERK1/2 in HUVECs (Figure 4). These results suggest that deguelin possesses a direct antimitotic effect on human endothelial cells, which may result in a reduction of cell proliferation, chemotactic motility, and tube formation.

Over-expression of c-Met or/and HGF has also been identified in the vast majority of solid tumors $[37,38]$. Researchers have reported that the activation of $\mathrm{HGF} / \mathrm{c}-\mathrm{Met}$ signaling in cancer cells promoted VEGF biosynthesis in a PI3K signaling pathway-dependent manner [30, 31, 39]. Interestingly, HGF has been shown to not only increase VEGF production but to also act synergistically with VEGF to induce tube formation and angiogenesis [40-42]. Therefore, HGF/c-Met could be a potentially useful antiangiogenic target in human cancers. More importantly, the HGF/c-Met signaling is one of the most frequently dysregulated pathways in hepatocellular carcinoma [43], targeting of this pathway directly suppressed tumor growth and metastasis by a dual blockade of VEGFR2 and c-Met activation [44]. Here, results showed that deguelin inhibited the secretion of VEGF in both HepG2 and Hep3B cells in an HGF/cMet signaling-depended manner (Figure 5). In agreement with the above results, the motility of endothelial cells triggered by VEGF in ex vivo and in vivo assays can be significantly inhibited by deguelin at low concentrations (Figure 2). Thus, the suppression of HGF/c-MET pathway in cancer cells may also contribute to the antitumor effects of deguelin through modulating the angiogenesis activity of human endothelial cells.

Receptor tyrosine kinase (RTK) pathways often regulate one another, and crosstalk between specific RTKs facilitates not only malignant tumor growth but also resistance to cancer therapy [45]. Disruption of either c-Met or VEGF only slowed tumor progression partially. More importantly, recent studies revealed that anti-VEGF or anti-angiogenesis cancer therapies promoted cancer metastasis [46-48]. Sennino and colleagues demonstrate that selectively inhibition of VEGF via the use of an anti-VEGF antibody increased 
invasion and metastasis in a c-Met-dependent manner. Strikingly, selective c-Met inhibition was sufficient to block these effects, providing a potential mechanism for and solution to overcome increased invasion in the face of anti-VEGF therapy [49]. These findings have potentially important translational implications, particularly for tumors that display significant coexpression or co-activation of c-Met and VEGFR in the malignant epithelial cell compartment. A promising strategy to overcome these limitations is to disrupt both
RTK pathways together either at the ligand-receptor level or downstream. Importantly, in order to confirm the in vivo antitumor activity of deguelin, we developed the PDX model by using 3 different orthotopic hepatocellular carcinomas which exhibit similar clinical characteristics (Table 1). Data showed that deguelin effectively inhibited tumor growth without any cytotoxicity (Figure $6)$. This result implied that deguelin may develop as a novel clinical therapeutic agent against hepatocellular carcinoma in the future.

A
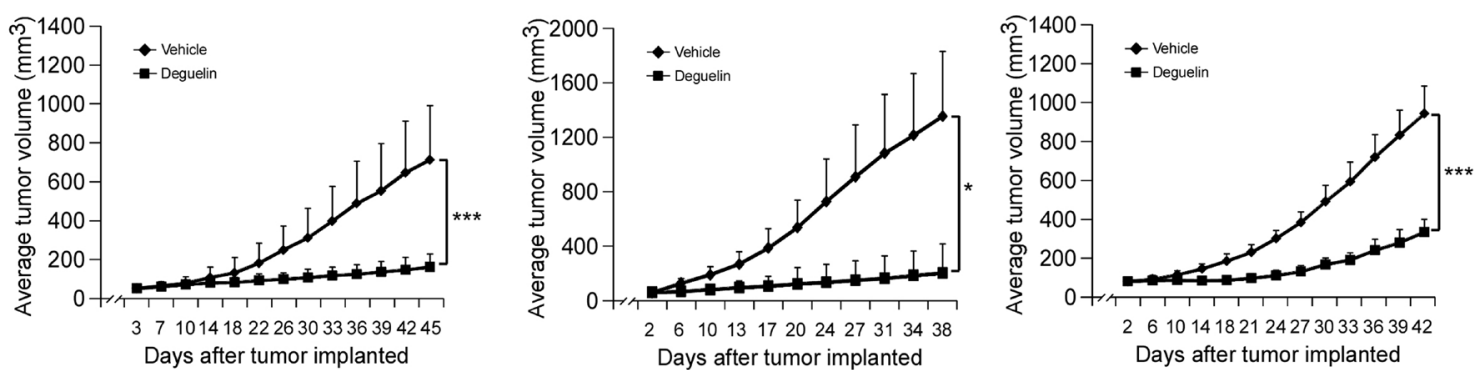

B
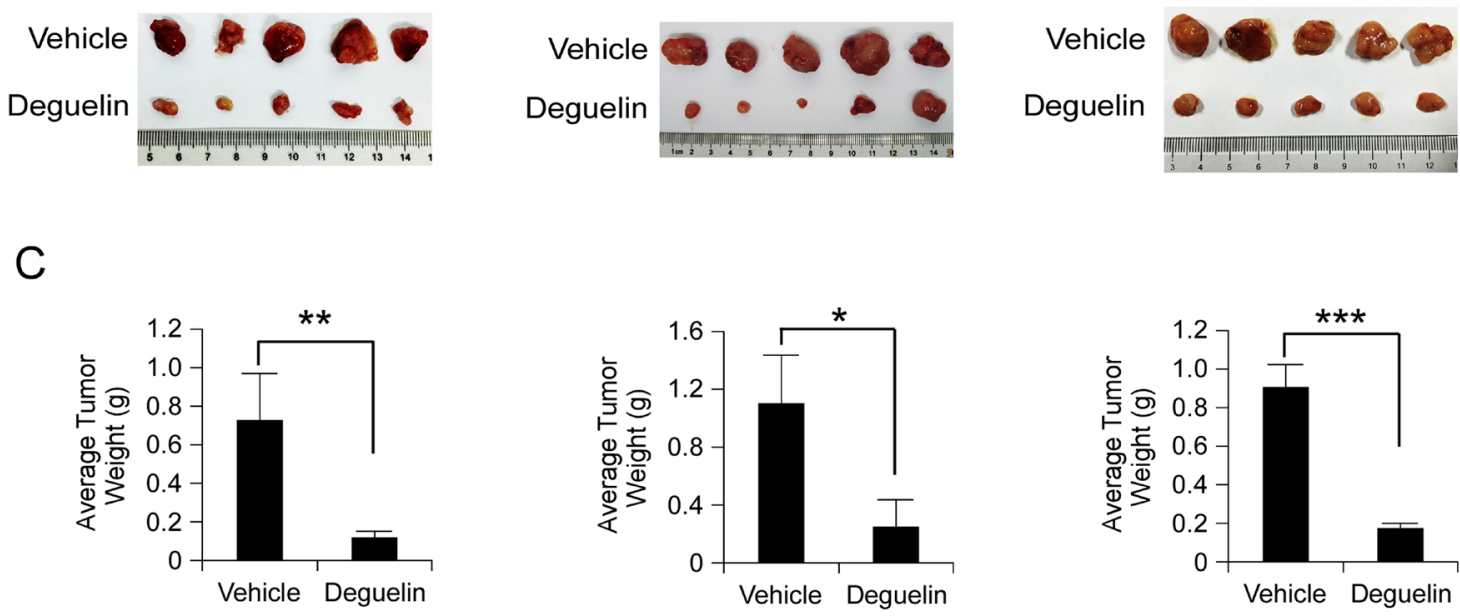

$\mathrm{D}$
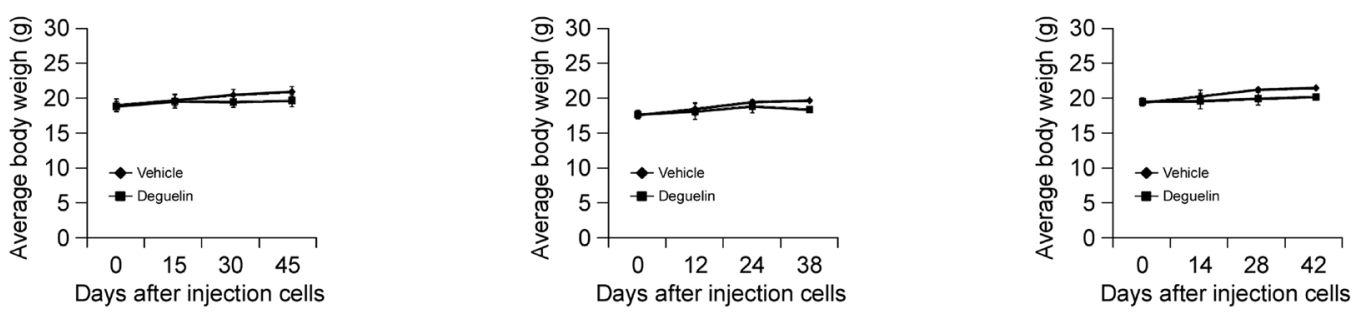

Figure 6: In vivo antitumor efficacy of deguelin in human hepatocellular PDX tumor models. (A-C) Deguelin significantly inhibits tumor growth in a PDX tumor model compared to a vehicle-treated group. B-17 SCID mice each implanted with a different patient's tumor were divided into 2 groups. Mice implanted with Case 1 (left, $n=10$ ), Case 2 (middle, $n=10$ ) or Case 3 (right, $n=10$ ) were treated every three days by i.p. injection with vehicle or deguelin. (A) Tumor growth curve. (B) Photograph of tumors in the vehicle and deguelin-treated group. (C) Average tumor weight. (D) The change of body weight of tumor-bearing mice during the experiment. Data are represented as mean values \pm S.D. The asterisks indicate significant differences $\left({ }^{*} p<0.05,{ }^{* *} p<0.01,{ }^{* *} p<0.001\right)$ between deguelin-treated and vehicle-treated group. 
Overall our study indicated that deguelin exerted potent anti-angiogenesis activities via specifically targeting HGF-c-Met and VEGF-VEGFR pathways in cancer cells and endothelial cells, respectively. Deguelin is a potent angiogenesis inhibitor with the potential to become a useful agent in the clinical treatment of human hepatocellular carcinoma.

\section{MATERIALS AND METHODS}

\section{Cell culture and reagents}

Cells (HUVECs, HepG2, and Hep3B) from American Type Culture Collection (ATCC) were cultured at $37^{\circ} \mathrm{C}$ in a humidified incubator with $5 \% \mathrm{CO}_{2}$ according to the ATCC protocols. Cells were cytogenetically tested and authenticated before being frozen. Each vial of frozen cells was thawed and maintained for 2 months (10 passages). MHCC97-H cells were purchased from Cell Bank of Chinese Academy of Sciences, Shanghai, China. Of note, HUVECs were cultured with M199, supplemented with 20\% FBS, Endothelial cell growth supplement $(30 \mu \mathrm{g} / \mathrm{ml})$ and heparin $(100 \mu \mathrm{g} / \mathrm{ml})$, Human liver cancer cells HepG2, Hep3B, and MHCC97-H were grown in Eagle's Minimum Essential Medium supplemented with 10\% FBS and antibiotics. Deguelin and chemical reagents, including Tris, $\mathrm{NaCl}, \mathrm{SDS}$, and DMSO, for molecular biology and buffer preparation, were purchased from Sigma-Aldrich (St. Louis, MO, USA) Gefitinib and Linsitinib were purchased from Selleckchem (Houston, TX, USA).

\section{MTS assay}

Human liver cancer cells were seeded $\left(3 \times 10^{3} /\right.$ well/100 $\mu \mathrm{l}$ ) into 96 -well plates and treated with various doses of deguelin for different time points as indicated. The viability was assessed by MTS assay (Promega, Madison, WI, USA) according to instructions provided.

\section{Anchorage-independent cell growth assay}

The anchorage-independent cell growth assay was performed as described previously [50]. Briefly, cells were suspended $(8,000$ cells $/ \mathrm{ml})$ in $1 \mathrm{ml}$ of $0.3 \%$ agar with Eagle's basal medium containing 10\% FBS, $1 \%$ antibiotics, and different concentrations of deguelin overlaid into six-well plates containing a $0.6 \%$ agar base. The cultures were maintained in a $37^{\circ} \mathrm{C}, 5 \% \mathrm{CO}_{2}$ incubator for 1 to 2 weeks, and then colonies were counted under a microscope using the Image-Pro Plus software program (Media Cybernetics, Silver Spring, MD, USA).

\section{Flow cytometry}

Flow cytometry was used to quantify cells in each phase of the cell cycle. Cells $\left(2 \times 10^{5}\right)$ were seeded into
6 well plates and treated with various concentrations of deguelin for $24 \mathrm{~h}$. Cells were harvested and washed with PBS for two times and then fixed in $70 \%$ ethanol overnight at $4^{\circ} \mathrm{C}$. Cells were counterstained in the dark with $50 \mu \mathrm{g} / \mathrm{ml}$ propidium iodide and $0.1 \%$ ribonuclease A (RNase A) in $400 \mu \mathrm{l}$ of PBS at $25^{\circ} \mathrm{C}$ for $30 \mathrm{~min}$. Stained cells were assayed and quantified using a FACSort Flow Cytometer (BD, San Jose, CA, USA).

\section{The motility assay}

The assay to measure motility of HUVECs was based on "scratch" wounding a confluent monolayer. Cells were seeded onto $0.1 \%$ gelatin-coated six-well plates in complete medium. After $24 \mathrm{~h}$, HUVECs were starved to inactivate cell proliferation when a confluent monolayer was formed. The cells were scratch wounded using the tip of a universal $10 \mu \mathrm{l}$ pipette tip. ECGM containing $0.5 \%$ FBS was added with or without $10 \mathrm{ng} / \mathrm{mL}$ VEGF and different concentrations of deguelin. After $12 \mathrm{~h}$ incubation, the cells were rinsed with PBS and randomly chosen fields were photographed under a light microscope. The number of migrated cells was counted.

\section{In vitro capillary tube formation}

HUVECs were pretreated with various dilutions of deguelin for $30 \mathrm{~min}$ and then seeded in 24 well plates coated with Matrigel (BD Biosciences, San Jose, CA, USA). After 6-8 h, tubular structures of endothelial cells were photographed using an inverted microscope (Olympus, Tokyo, Japan). Three independent experiments were performed.

\section{Invasion assay}

An invasion assay was conducted using a modified Boyden chamber and Matrigel (BD Bioscience)-coated polycarbonate nucleopore membranes (Corning; 8- $\mu \mathrm{m}$ pore size). Serum-free medium containing VEGF (10 ng/mL) was pipetted into the lower wells. HUVECs were trypsinized and suspended at a density of $1 \times 10^{5}$ cells $/ 100 \mu \mathrm{l}$ in serum-free medium without VEGF. Cells were then pretreated with deguelin for $30 \mathrm{~min}$ and $100 \mu \mathrm{l}$ of the cell suspension were loaded into the upper wells. The chamber was incubated in a $5 \% \mathrm{CO} 2$ incubator at $37^{\circ} \mathrm{C}$. After $8 \mathrm{~h}$ of incubation, the membrane was fixed and stained with crystal violet solution. Invasiveness was determined by counting the cells that passed through the filter.

\section{In vivo matrigel plug assay}

Growth factor-reduced Matrigel (BD Biosciences) containing $80 \mathrm{ng}$ VEGF and 20 units of heparin with or without deguelin were implanted subcutaneously into C57/BL/6 mice. After 7 days, the mice were euthanized and Matrigel plugs were removed. H\&E staining was 
performed and functional microvessels were quantified manually using a microscope to identify the formation of new microvessels.

\section{VEGFR2 inhibition assay}

The in vitro VEGFR2 inhibition assay was performed using the HTScan ${ }^{\circledR}$ VEGF Receptor 2 Kinase Assay Kit (\#7788, Cell Signaling Technology) according to manufacturers' standard procedures.

\section{Protein preparation and western blotting}

Protein samples were extracted with RIPA buffer (10 mM Tris-Cl (pH 8.0), 1 mM EDTA, $0.5 \mathrm{mM}$ EGTA, 1\% Triton X-100, 0.1\% sodium deoxycholate, $0.1 \% \mathrm{SDS}, 140 \mathrm{mM} \mathrm{NaCl}$ ). Protein concentration was determined using the BCA Assay Reagent (Pierce, Rockford, IL, USA). For immunoblotting, proteins $(30 \mu \mathrm{g})$ were detected with specific antibodies and an HRP-conjugated secondary antibody. Primary antibodies were used for immunoblotting: p-VEGFR (\#2478, 1:1000), VEGFR (\#9698, 1:2000), p-Akt (\#4060, 1:1000), panAkt (\#4691, 1:2000), p-ERK1/2 (\#8544, 1:2000), ERK1/2 (\#4695, 1:2000), p-EGFR(\#3777, 1:1000), EGFR (\#\#4267, 1:2000), p-IGF1R $\beta$ (\#28897, 1:1000), IGF1R $\beta$ (\#9750), p-cMet (\#3077, 1:1000) and c-Met (\#8198, 1:2000) from Cell Signaling Technology; $\beta$-Actin (A5316, 1:10000) from Sigma-Aldrich. Secondary antibodies anti-rabbit IgG HRP (\#7074, 1:10000) and anti-mouse IgG HRP (\#7076, 1:10000) were purchased from Cell Signaling Technology. Antibody conjugates were visualized by chemiluminescence (ECL, Thermo Scientific, USA).

\section{Lentiviral infection}

Lentivirus plasmids containing $p L K O .1-s h c-M e t$ (TRCN0000040043, TRCN0000040044), pLKO.1shEGFR (TRCN0000039633, TRCN0000039636) and $\quad p L K O .1$-shIGFIR $\beta \quad$ (TRCN0000000422, TRCN0000000426) were purchased from GE Dharmacon. The c-Met overexpression plasmid (RC217003) was purchased from OriGene Technologies, Inc. (Rockville, MD, USA). The pLKO.1-shGFP (Addgene plasmid \#30323), the lentiviral packaging plasmid psPAX2 (Addgene plasmid \#12260) and the envelope plasmid pMD2.G (Addgene plasmid \#12259) were available on Addgene (Cambridge, MA). The generation of gene stable knocking down cell lines was performed as described previously [51]. Briefly, $p L K O .1-s h-G F P$ or $p L K O .1$ shRNA lentivirus plasmids were co-transfected into $293 T$ cells with $p s P A X 2$ and $p M D 2-G$. Viral supernatant fractions were collected at 48 hours after transfection and filtered through a $0.45 \mu \mathrm{m}$ filter followed by infection into cells together with $10 \mu \mathrm{g} / \mathrm{mL}$ polybrene. At 16 hours after infection, the medium was replaced with fresh medium containing $1 \mu \mathrm{g} / \mathrm{ml}$ puromycin and cells were incubated for another 6 days.

\section{VEGF ELISA assay}

Human VEGF was measured by ELISA kit (R\&D Systems, Minneapolis, MN, USA), according to the manufacturer's instructions. Each sample was analyzed in duplicate.

\section{In vivo tumor growth assay}

All the experimentation for animals was approved by the Animal Ethics Committee of Central South University, following the Guidelines of Animal Handling and Care in Medical Research from Hunan Province, China. HepG2 cells $\left(3 \times 10^{6}\right)$ in $100 \mu \mathrm{l}$ RPMI-1640 medium were inoculated s.c. into the right flank of 6-week-old female athymic nude mice. Nude mice $(n=5)$ were randomly divided into groups when tumor volume reached 50 to $100 \mathrm{~mm}^{3}$. The dosage of deguelin was $4 \mathrm{mg} / \mathrm{kg}$ and was administrated every three days by intraperitoneal injection, whereas control mice were administered vehicle. The body weight of each mouse was recorded and tumor volume was determined by vernier caliper twice a week. Volume was calculated following the formula of $\mathrm{A} \times \mathrm{B}^{2} \times 0.5$, wherein $\mathrm{A}$ is the longest diameter of tumor, $\mathrm{B}$ is the shortest diameter and $\mathrm{B}^{2}$ is $\mathrm{B}$ squared. Mice were monitored until day 34 and at that time mice were euthanized and tumors extracted.

\section{Establishment of PDX model}

Human tissue collection and use protocols were approved by the ethics committee of Central South University, Changsha, Hunan, China. Hepatocellular carcinoma samples were obtained from 3 patients who were informed and provided written consent. Patients were treated with surgery at the Third Xiangya Hospital of Central South University (Changsha, Hunan, China). Pathologic and clinical data were entered and maintained in our prospective database.

The method was performed as described previously [52]. Briefly, fresh tumor tissue fragments were collected and transferred into an ice-cold serum-free RPMI-1640 medium with antibiotics. Within $2 \mathrm{~h}$ of surgical resection, tumor tissues were trimmed, cut into 3-5 mm sizes and implanted subcutaneously in anesthetized 6 to 8 week old female C.B-17 severe combined immunodeficient (SCID) mice (Vital River Laboratories Co., Ltd., Beijing, China). Once mass formation reached about $1500 \mathrm{~mm}^{3}$, mice of this first generation of xenografts (named P1) were sacrificed and the tumors were passaged and expanded for 2 more generations (named P2 and P3). When P3 tumors reached an average volume of $50-100 \mathrm{~mm}^{3}$, mice were divided into 2 groups ( $n=5$ mice per group) and treated with vehicle, or $4 \mathrm{mg} / \mathrm{kg}$ deguelin, respectively, every 
3 days by intraperitoneal (i.p.) injection. Tumor volume and body weight were determined by vernier caliper twice a week.

\section{Immunohistochemical analysis}

A Vectastain Elite ABC Kit (Vector Laboratories; Burlingame, CA) was used for immunohistochemical staining according to the recommended protocol. Briefly, the slide was baked at $60^{\circ} \mathrm{C}$ for $2 \mathrm{~h}$, deparaffinized, and rehydrated. To expose antigens, the slide was unmasked by submersion into boiling sodium citrate buffer (10 mM, pH 6.0) for $10 \mathrm{~min}$, and then treated with $3 \%$ $\mathrm{H}_{2} \mathrm{O}_{2}$ for 10 min. The slide was blocked with $50 \%$ goat serum albumin in $1 \times$ PBS in a humidified chamber for $1 \mathrm{~h}$ at room temperature and then with a first antibody (1:100 dilution in $50 \%$ goat serum with PBS) at $4^{\circ} \mathrm{C}$ in a humidified chamber overnight. The slide was washed and hybridized with the secondary antibody from Vector Laboratories (Burlingame, CA) (anti-rabbit 1:200) for $1 \mathrm{~h}$ at room temperature. Slides were stained using the Vectastain Elite ABC kit.

\section{Statistical analysis}

Standard statistical methods were performed using Statistics Package for Social Science (SPSS) software (version 13.0; SPSS, Chicago, IL, USA). All data are presented as mean values \pm S.D. as indicated and analyzed using the Student's $t$-test or ANOVA. A $p$ value $<0.05$ was considered statistically significant.

\section{Abbreviations}

HCC, hepatocellular carcinoma; VEGF, vascular endothelial growth factor; HUVECs, human umbilical vascular endothelial cells; HGF, hepatocyte growth factor.

\section{ACKNOWLEDGMENTS AND FUNDING}

This work was supported by National Natural Science Foundation of China (No.81401548, No.81572280, No.81371690, and No.81502121) and Research Project of Health and Family Planning Commission of Hunan Province (B2016125). We want to acknowledge the technical and financial support of the State Key Laboratory of Powder Metallurgy, Central South University.

\section{CONFLICTS OF INTEREST}

The authors declare that they have no conflict of interest.

\section{REFERENCES}

1. Chung AS, Lee J, Ferrara N. Targeting the tumour vasculature: insights from physiological angiogenesis. Nat Rev Cancer. 2010; 10:505-514.

2. Mehlen P, Puisieux A. Metastasis: A question of life or death. Nat Rev Cancer. 2006; 6:449-458.

3. Lamalice L, Le Boeuf F, Huot J. Endothelial cell migration during angiogenesis. Circ Res. 2007; 100:782-794.

4. Ferrara N, Gerber HP, LeCouter J. The biology of VEGF and its receptors. Nat Med. 2003; 9:669-676.

5. Olsson AK, Dimberg A, Kreuger J, Claesson-Welsh L. VEGF receptor signalling - in control of vascular function. Nat Rev Mol Cell Biol. 2006; 7:359-371.

6. Gu Y, Korbel C, Scheuer C, Nenicu A, Menger MD, Laschke MW. Tubeimoside-1 suppresses tumor angiogenesis by stimulation of proteasomal VEGFR2 and Tie2 degradation in a non-small cell lung cancer xenograft model. Oncotarget. 2016; 7:5258-5272. https://doi.org/10.18632/oncotarget.6676.

7. Ellis LM, Hicklin DJ. VEGF-targeted therapy: mechanisms of anti-tumour activity. Nat Rev Cancer. 2008; 8:579-591.

8. Tu Y, Liu L, Zhao D, Liu Y, Ma X, Fan Y, Wan L, Huang T, Cheng Z, Shen B. Overexpression of miRNA-497 inhibits tumor angiogenesis by targeting VEGFR2. Sci Rep. 2015; $5: 13827$.

9. El-Serag HB, Mason AC. Rising incidence of hepatocellular carcinoma in the United States. N Engl J Med. 1999; 340:745-750.

10. Farazi PA, DePinho RA. Hepatocellular carcinoma pathogenesis: from genes to environment. Nat Rev Cancer. 2006; 6:674-687.

11. Zhu AX, Duda DG, Sahani DV, Jain RK. HCC and angiogenesis: possible targets and future directions. Nat Rev Clin Oncol. 2011; 8:292-301.

12. Potente M, Gerhardt H, Carmeliet P. Basic and therapeutic aspects of angiogenesis. Cell. 2011; 146:873-887.

13. Siegel AB, Cohen EI, Ocean A, Lehrer D, Goldenberg A, Knox JJ, Chen H, Clark-Garvey S, Weinberg A, Mandeli J, Christos P, Mazumdar M, Popa E, et al. Phase II trial evaluating the clinical and biologic effects of bevacizumab in unresectable hepatocellular carcinoma. J Clin Oncol. 2008; 26:2992-2998.

14. Llovet JM, Ricci S, Mazzaferro V, Hilgard P, Gane E, Blanc JF, de Oliveira AC, Santoro A, Raoul JL, Forner A, Schwartz M, Porta C, Zeuzem S, et al. Sorafenib in advanced hepatocellular carcinoma. N Engl J Med. 2008; 359:378-390.

15. Abou-Alfa GK, Schwartz L, Ricci S, Amadori D, Santoro A, Figer A, De Greve J, Douillard JY, Lathia C, Schwartz B, Taylor I, Moscovici M, Saltz LB. Phase II study of sorafenib in patients with advanced hepatocellular carcinoma. J Clin Oncol. 2006; 24:4293-4300. 
16. Cheng AL, Kang YK, Lin DY, Park JW, Kudo M, Qin S, Chung HC, Song X, Xu J, Poggi G, Omata M, Pitman Lowenthal S, Lanzalone S, et al. Sunitinib versus sorafenib in advanced hepatocellular cancer: results of a randomized phase III trial. J Clin Oncol. 2013; 31:4067-4075.

17. Zhu AX, Sahani DV, Duda DG, di Tomaso E, Ancukiewicz M, Catalano OA, Sindhwani V, Blaszkowsky LS, Yoon SS, Lahdenranta J, Bhargava P, Meyerhardt J, Clark JW, et al. Efficacy, safety, and potential biomarkers of sunitinib monotherapy in advanced hepatocellular carcinoma: a phase II study. J Clin Oncol. 2009; 27:3027-3035.

18. Lee HY, Oh SH, Woo JK, Kim WY, Van Pelt CS, Price RE, Cody D, Tran H, Pezzuto JM, Moriarty RM, Hong WK. Chemopreventive effects of deguelin, a novel Akt inhibitor, on tobacco-induced lung tumorigenesis. J Natl Cancer Inst. 2005; 97:1695-1699.

19. Yan B, Zhao D, Yao Y, Bao Z, Lu G, Zhou J. Deguelin Induces the Apoptosis of Lung Squamous Cell Carcinoma Cells through Regulating the Expression of Galectin-1. Int J Biol Sci. 2016; 12:850-860.

20. Hsu YC, Chiang JH, Yu CS, Hsia TC, Wu RS, Lien JC, Lai $\mathrm{KC}$, Yu FS, Chung JG. Antitumor effects of deguelin on H460 human lung cancer cells in vitro and in vivo: Roles of apoptotic cell death and H460 tumor xenografts model. Environ Toxicol. 2017; 32:84-98.

21. Murillo G, Salti GI, Kosmeder JW 2nd, Pezzuto JM, Mehta RG. Deguelin inhibits the growth of colon cancer cells through the induction of apoptosis and cell cycle arrest. Eur J Cancer. 2002; 38:2446-2454.

22. Xu XD, Zhao Y, Zhang M, He RZ, Shi XH, Guo XJ, Shi CJ, Peng F, Wang M, Shen M, Wang X, Li X, Qin RY. Inhibition of Autophagy by Deguelin Sensitizes Pancreatic Cancer Cells to Doxorubicin. Int J Mol Sci. 2017; 18.

23. Thamilselvan V, Menon M, Thamilselvan S. Anticancer efficacy of deguelin in human prostate cancer cells targeting glycogen synthase kinase-3 beta/beta-catenin pathway. Int J Cancer. 2011; 129:2916-2927.

24. Wu W, Hai Y, Chen L, Liu RJ, Han YX, Li WH, Li S, Lin S, Wu XR. Deguelin-induced blockade of PI3K/protein kinase B/ MAP kinase signaling in zebrafish and breast cancer cell lines is mediated by down-regulation of fibroblast growth factor receptor 4 activity. Pharmacol Res Perspect. 2016; 4:e00212.

25. Robles AJ, Cai S, Cichewicz RH, Mooberry SL. Selective activity of deguelin identifies therapeutic targets for androgen receptor-positive breast cancer. Breast Cancer Res Treat. 2016; 157:475-488.

26. Wang Y, Ma W, Zheng W. Deguelin, a novel antitumorigenic agent targeting apoptosis, cell cycle arrest and anti-angiogenesis for cancer chemoprevention. Mol Clin Oncol. 2013; 1:215-219.

27. Baba Y, Fujii M, Maeda T, Suzuki A, Yuzawa S, Kato Y. Deguelin induces apoptosis by targeting both EGFR-Akt and IGF1R-Akt pathways in head and neck squamous cell cancer cell lines. Biomed Res Int. 2015; 2015:657179.
28. Dell'Eva R, Ambrosini C, Minghelli S, Noonan DM, Albini A, Ferrari N. The Akt inhibitor deguelin, is an angiopreventive agent also acting on the NF-kappaB pathway. Carcinogenesis. 2007; 28:404-413.

29. Goyal L, Muzumdar MD, Zhu AX. Targeting the HGF/cMET pathway in hepatocellular carcinoma. Clin Cancer Res. 2013; 19:2310-2318.

30. Matsumura A, Kubota T, Taiyoh H, Fujiwara H, Okamoto K, Ichikawa D, Shiozaki A, Komatsu S, Nakanishi M, Kuriu Y, Murayama Y, Ikoma H, Ochiai T, et al. HGF regulates VEGF expression via the c-Met receptor downstream pathways, PI3K/Akt, MAPK and STAT3, in CT26 murine cells. Int J Oncol. 2013; 42:535-542.

31. Lin YM, Huang YL, Fong YC, Tsai CH, Chou MC, Tang $\mathrm{CH}$. Hepatocyte growth factor increases vascular endothelial growth factor-A production in human synovial fibroblasts through c-Met receptor pathway. PLoS One. 2012; 7:e50924.

32. Hu J, Ye H, Fu A, Chen X, Wang Y, Ye X, Xiao W, Duan X, Wei Y, Chen L. Deguelin--an inhibitor to tumor lymphangiogenesis and lymphatic metastasis by downregulation of vascular endothelial cell growth factor-D in lung tumor model. Int $\mathrm{J}$ Cancer. 2010; 127:2455-2466.

33. Oh SH, Woo JK, Jin Q, Kang HJ, Jeong JW, Kim KW, Hong WK, Lee HY. Identification of novel antiangiogenic anticancer activities of deguelin targeting hypoxia-inducible factor-1 alpha. Int J Cancer. 2008; 122:5-14.

34. Lee H, Lee JH, Jung KH, Hong SS. Deguelin promotes apoptosis and inhibits angiogenesis of gastric cancer. Oncol Rep. 2010; 24:957-963.

35. Lee JH, Lee DH, Lee HS, Choi JS, Kim KW, Hong SS. Deguelin inhibits human hepatocellular carcinoma by antiangiogenesis and apoptosis. Oncol Rep. 2008; 20:129-134.

36. Hicklin DJ, Ellis LM. Role of the vascular endothelial growth factor pathway in tumor growth and angiogenesis. J Clin Oncol. 2005; 23:1011-1027.

37. Gherardi E, Birchmeier W, Birchmeier C, Vande Woude G. Targeting MET in cancer: rationale and progress. Nat Rev Cancer. 2012; 12:89-103.

38. Awad MM, Oxnard GR, Jackman DM, Savukoski DO, Hall D, Shivdasani P, Heng JC, Dahlberg SE, Janne PA, Verma S, Christensen J, Hammerman PS, Sholl LM. MET Exon 14 Mutations in Non-Small-Cell Lung Cancer Are Associated With Advanced Age and Stage-Dependent MET Genomic Amplification and c-Met Overexpression. J Clin Oncol. 2016; 34:721-730.

39. Dong G, Chen Z, Li ZY, Yeh NT, Bancroft CC, Van Waes C. Hepatocyte growth factor/scatter factor-induced activation of MEK and PI3K signal pathways contributes to expression of proangiogenic cytokines interleukin-8 and vascular endothelial growth factor in head and neck squamous cell carcinoma. Cancer Res. 2001; 61:5911-5918. 
40. Sulpice E, Ding S, Muscatelli-Groux B, Berge M, Han ZC, Plouet J, Tobelem G, Merkulova-Rainon T. Cross-talk between the VEGF-A and HGF signalling pathways in endothelial cells. Biol Cell. 2009; 101:525-539.

41. You WK, Sennino B, Williamson CW, Falcon B, Hashizume H, Yao LC, Aftab DT, McDonald DM. VEGF and c-Met blockade amplify angiogenesis inhibition in pancreatic islet cancer. Cancer Res. 2011; 71:4758-4768.

42. Shojaei F, Lee JH, Simmons BH, Wong A, Esparza CO, Plumlee PA, Feng J, Stewart AE, Hu-Lowe DD, Christensen JG. HGF/c-Met acts as an alternative angiogenic pathway in sunitinib-resistant tumors. Cancer Res. 2010; 70:10090-10100.

43. Giordano S, Columbano A. Met as a therapeutic target in HCC: facts and hopes. J Hepatol. 2014; 60:442-452.

44. Xiang Q, Chen W, Ren M, Wang J, Zhang H, Deng DY, Zhang L, Shang C, Chen Y. Cabozantinib suppresses tumor growth and metastasis in hepatocellular carcinoma by a dual blockade of VEGFR2 and MET. Clin Cancer Res. 2014; 20:2959-2970.

45. Casaletto JB, McClatchey AI. Spatial regulation of receptor tyrosine kinases in development and cancer. Nat Rev Cancer. 2012; 12:387-400.

46. Loges S, Schmidt T, Carmeliet P. Mechanisms of resistance to anti-angiogenic therapy and development of thirdgeneration anti-angiogenic drug candidates. Genes Cancer. 2010; 1:12-25. https://doi.org/10.1177/1947601909356574.

47. Hecht JR, Mitchell E, Chidiac T, Scroggin C, Hagenstad C, Spigel D, Marshall J, Cohn A, McCollum D, Stella P, Deeter R, Shahin S, Amado RG. A randomized phase IIIB trial of chemotherapy, bevacizumab, and panitumumab compared with chemotherapy and bevacizumab alone for metastatic colorectal cancer. J Clin Oncol. 2009; 27:672-680.

48. Tol J, Koopman M, Cats A, Rodenburg CJ, Creemers GJ, Schrama JG, Erdkamp FL, Vos AH, van Groeningen CJ, Sinnige HA, Richel DJ, Voest EE, Dijkstra JR, et al. Chemotherapy, bevacizumab, and cetuximab in metastatic colorectal cancer. N Engl J Med. 2009; 360:563-572.

49. Sennino B, Ishiguro-Oonuma T, Wei Y, Naylor RM, Williamson CW, Bhagwandin V, Tabruyn SP, You WK, Chapman HA, Christensen JG, Aftab DT, McDonald DM. Suppression of tumor invasion and metastasis by concurrent inhibition of c-Met and VEGF signaling in pancreatic neuroendocrine tumors. Cancer Discov. 2012; 2:270-287.

50. Liu H, Li W, Yu X, Gao F, Duan Z, Ma X, Tan S, Yuan Y, Liu L, Wang J, Zhou X, Yang Y. EZH2-mediated Puma gene repression regulates non-small cell lung cancer cell proliferation and cisplatin-induced apoptosis. Oncotarget. 2016; 7:56338-56354. https://doi.org/10.18632/ oncotarget.10841.

51. Li W, Peng C, Lee MH, Lim D, Zhu F, Fu Y, Yang G, Sheng Y, Xiao L, Dong X, Ma W, Bode AM, Cao Y, et al. TRAF4 is a critical molecule for Akt activation in lung cancer. Cancer Res. 2013; 73:6938-6950.

52. Sheng Y, Liu K, Wu Q, Oi N, Chen H, Reddy K, Jiang Y, Yao K, Li H, Li W, Zhang Y, Saleem M, Ma WY, et al. PPMP, a novel tubulin-depolymerizing agent against esophageal cancer in patient-derived tumor xenografts. Oncotarget. 2016; 7:30977-89. https://doi.org/10.18632/oncotarget.9050. 